\title{
Enhancing Growth and Glucosinolate Accumulation in Watercress (Nasturtium officinale L.) by Regulating Light Intensity and Photoperiod in Plant Factories
}

\author{
Vu Phong Lam ${ }^{1,2}$, Jaeyun Choi ${ }^{1}$ and Jongseok Park ${ }^{1,3, *(\mathbb{D})}$ \\ 1 Department of Horticultural Science, Chungnam National University, Daejeon 34134, Korea; \\ phonglamdhtaybac@gmail.com (V.P.L.); teuk0207@naver.com (J.C.) \\ 2 Department of Agronomy, Tay Bac University, Son La 360000, Vietnam \\ 3 Graduate School of Bio-AI Convergence, Chungnam National University, Daejeon 34134, Korea \\ * Correspondence: jongseok@cnu.ac.kr; Tel.: +82-42-821-5737
}

\section{check for}

updates

Citation: Lam, V.P.; Choi, J.; Park, J. Enhancing Growth and Glucosinolate Accumulation in Watercress (Nasturtium officinale L.) by Regulating Light Intensity and Photoperiod in Plant Factories. Agriculture 2021, 11, 723. https:// doi.org/10.3390/agriculture11080723

Academic Editors: Athanasios Koukounaras, Filippos Bantis and Éva Darkó

Received: 22 June 2021

Accepted: 27 July 2021

Published: 30 July 2021

Publisher's Note: MDPI stays neutral with regard to jurisdictional claims in published maps and institutional affiliations.

Copyright: (c) 2021 by the authors. Licensee MDPI, Basel, Switzerland. This article is an open access article distributed under the terms and conditions of the Creative Commons Attribution (CC BY) license (https:// creativecommons.org/licenses/by/ $4.0 /)$.

\begin{abstract}
Recent advancements in light-emitting diode technology provide an opportunity to evaluate the correlation between different light sources and plant growth as well as their secondary metabolites. The aim of this study was to determine the optimal light intensity and photoperiod for increasing plant growth and glucosinolate concentration and content in watercress. Two-week-old seedlings were transplanted in a semi-deep flow technique system of a plant factory for 28 days under four photoperiod-light intensity treatments $\left(12 \mathrm{~h}-266 \mu \mathrm{mol} \cdot \mathrm{m}^{-2} \cdot \mathrm{s}^{-1}, 16 \mathrm{~h}-200 \mu \mathrm{mol} \cdot \mathrm{m}^{-2} \cdot \mathrm{s}^{-1}\right.$, $20 \mathrm{~h}-160 \mu \mathrm{mol} \cdot \mathrm{m}^{-2} \cdot \mathrm{s}^{-1}$, and $24 \mathrm{~h}-133 \mu \mathrm{mol} \cdot \mathrm{m}^{-2} \cdot \mathrm{s}^{-1}$ ) with the same daily light integral. The mean values of shoot fresh and dry weights were the highest under the $20 \mathrm{~h}-160 \mu \mathrm{mol} \cdot \mathrm{m}^{-2} \cdot \mathrm{s}^{-1}$ treatment, although there was no significant difference. Net photosynthesis and stomatal conductance gradually decreased with decreasing light intensity and increasing photoperiod. However, total glucosinolate concentration was significantly higher under $20 \mathrm{~h}-160 \mu \mathrm{mol} \cdot \mathrm{m}^{-2} \cdot \mathrm{s}^{-1}$ and $24 \mathrm{~h}-133 \mu \mathrm{mol} \cdot \mathrm{m}^{-2} \cdot \mathrm{s}^{-1}$ compared with $12 \mathrm{~h}-266 \mu \mathrm{mol} \cdot \mathrm{m}^{-2} \cdot \mathrm{s}^{-1}$ and $16 \mathrm{~h}-200 \mu \mathrm{mol} \cdot \mathrm{m}^{-2} \cdot \mathrm{s}^{-1}$. The total glucosinolate content was the greatest under $20 \mathrm{~h}-160 \mu \mathrm{mol} \cdot \mathrm{m}^{-2} \cdot \mathrm{s}^{-1}$ treatment. These data suggest that the $20 \mathrm{~h}-160 \mu \mathrm{mol} \cdot \mathrm{m}^{-2} \cdot \mathrm{s}^{-1}$ treatment promoted the maximum shoot biomass and glucosinolate content in watercress. This study supplies the optimal light strategies for the future industrial large-watercress cultivation.
\end{abstract}

Keywords: deep flow technique; glucosinolate; light-emitting diode; net photosynthesis; shoot biomass; watercress

\section{Introduction}

Watercress (Nasturtium officinale L.; Brassicaceae) is a semi-aquatic or aquatic perennial herb mainly cultivated in Asia, North and South America, and Europe [1]. Watercress is evaluated as an aquatic weed in some regions. It is used in soups (as garnish), fresh salads, and in other dishes [2]. The European Food Safety Authority has indicated that watercress is a safe vegetable of the group "herbs, edible flowers, and leaf vegetables" [3]. The US Centers for Disease Control and Prevention selected watercress as one of the crops containing the highest nutrient content per calorie [4]. It contains compounds such as vitamins, polyphenols, carotenoids, and isothiocyanates, and glucosinolates are the most crucial components present in watercress [2]. Watercress is a known medicine for treating cough, bronchial problems, and asthma [5]. Watercress has pharmacological actions such as antioxidant, anti-inflammatory, cardioprotective actions, antipsoriatic, antibacterial, and anticancer properties [1,2,6,7]. Because of the abundance of chemical components, watercress can be used in the food, medicine, and cosmetics industries.

Growing plants in a plant factory using artificial light is an efficient method of agricultural cultivation for combating climate change and worldwide food shortage [8]. Water shortages, unusual weather, and depletion of the agricultural land area result in a 
decrease in field crop production globally $[9,10]$. Nevertheless, these environmental problems do not affect crop production in a closed plant factory as the conditions for growth are controlled using temperature regulation, air conditioning, air circulation fans, artificial light, nutrient solutions, and $\mathrm{CO}_{2}$ enrichment [11,12]. Crops cultivated in a plant factory always depend on artificial light (light intensity, photoperiod, and light quality), which controls the photosynthetic process, plant physiology, biochemistry, and morphology [13,14]. Thus, upgrading the light source efficiency would significantly decrease the expense of the plant factory system, which in turn would promote sustainable cultivation because the impacts of ecological and costs could be decreased.

The lighting can be supplied for plants at uniform and fixed times with specificwavelength illumination in a plant factory because lighting schedules can be controlled, and particular photoperiods can be adjusted to promote plant growth and quality. For example, longer photoperiods increased the fresh weight of lettuce [15]. The growth of lettuce was increased with longer photoperiods and lower photosynthetic photon flux density (PPFD) at the same daily light integral (DLI) because the longer photoperiods compensated for a lower PPFD [16]. The growth of Achimenes cultivars grown under a low light intensity and longer photoperiods was higher as compared to that of those grown under a high light intensity and shorter photoperiods at the same DLI [17]. In addition, plant growth and morphology changes were reported due to changes in light intensity and photoperiod [18]. In general, these reports indicated that plant growth can be promoted under longer photoperiods with the same DLI. There have been several studies on the influences of different light intensities [19-21] and a combination of photoperiods and light intensities on plant biomass and secondary metabolites $[15,22,23]$. The optimum plant growth, yield, and quality can be obtained by controlling the light-emitting diode photoperiod and light quality $[24,25]$. Therefore, establishing a light regime that provides a favorable light photoperiod and intensity for plant growth and development is an essential step in cultivating plants in hydroponic systems in plant factories.

To date, several studies have been conducted on the influence of different light qualities, photoperiods, and light intensities on the growth and quality of watercress [26,27]. However, the effects of different light intensities in combination with different photoperiods on the growth and glucosinolate concentration and content of watercress grown in a plant factory have not yet been reported. For year-round production of good quality watercress in plant factories, it is important to understand the growth and quality responses to combined conditions of two light factors including photoperiod and light intensity. Thus, the aim of this study was to find the optimal light intensity and photoperiod treatment to increase plant growth and glucosinolate content in watercress. We hypothesized that plant growth and glucosinolate content in watercress increase with the increase of light intensity and photoperiod treatment.

\section{Materials and Methods}

\subsection{Seedling Conditions}

Watercress seeds were sown in rockwool cubes (240 holes; UR Rockwool, Suwon, Korea) and grown in a plant factory for 2 weeks. The air temperature and relative humidity in the plant factory were controlled at $20 \pm 2{ }^{\circ} \mathrm{C}$ and $60 \pm 10 \%$, respectively. White fluorescent lamps (TL5 14W/865 Philips, Amsterdam, Netherlands) were used for illumination. The photoperiod and PPFD were adjusted to $16 \mathrm{~h}$ per day and $150 \mu \mathrm{mol} \cdot \mathrm{m}^{-2} \cdot \mathrm{s}^{-1}$, respectively. The Hoagland solution for watercress seedlings (electrical conductivity $0.8 \mathrm{dS} \cdot \mathrm{m}^{-1}$; $\mathrm{pH}$ 6.0) was supplied from 1 week after sowing.

\subsection{Treatments}

Two weeks after sowing, the seedlings were transplanted into four lighting treatments in a plant factory with the same daily light integral $\left(11.52 \mathrm{~mol} \mathrm{~m}^{-2} \mathrm{~d}^{-1}\right)$. Each treatment had 10 plants. The $12 \mathrm{~h}-266 \mu \mathrm{mol}$ treatment photoperiod was set to $12 \mathrm{~h}$ per day with a PPFD of $266 \mu \mathrm{mol} \cdot \mathrm{m}^{-2} \cdot \mathrm{s}^{-1}$. The $16 \mathrm{~h}-200 \mu \mathrm{mol}$ treatment photoperiod was set to $16 \mathrm{~h}$ 
per day with a PPFD of $200 \mu \mathrm{mol} \cdot \mathrm{m}^{-2} \cdot \mathrm{s}^{-1}$. The $20 \mathrm{~h}-160 \mu$ mol treatment photoperiod was set to $20 \mathrm{~h}$ per day with a PPFD of $160 \mu \mathrm{mol} \cdot \mathrm{m}^{-2} \cdot \mathrm{s}^{-1}$. The $24 \mathrm{~h}-133 \mu \mathrm{mol}$ treatment photoperiod was set to $24 \mathrm{~h}$ per day with a PPFD of $133 \mu \mathrm{mol} \cdot \mathrm{m}^{-2} \cdot \mathrm{s}^{-1}$. Plants were cultivated under a 7:3 ratio of red/blue light-emitting diodes (LEDs) for 28 days under $400 \mu \mathrm{mol} \cdot \mathrm{mol}^{-1} \mathrm{CO}_{2}$ concentration and $60 \% \pm 10 \%$ relative humidity. The blue and red LEDs had a peak wavelength of 450 and $660 \mathrm{~nm}$, respectively. The experiment was conducted with two replicates for each treatment. The Hoagland nutrient solution for watercress plants (EC $2.0 \mathrm{dS} \cdot \mathrm{m}^{-1} ; \mathrm{pH}$ 6.0) was supplied for 28 days. The day and night air temperatures were controlled at 22 and $20^{\circ} \mathrm{C}$, respectively.

\subsection{Measurement of Photosynthetic Parameters and SPAD Value}

The net photosynthetic rate and stomatal conductance of fully expanded leaves were measured with a portable photosynthesis system (LI-6400; Li-Cor, Lincoln, NE, USA) at 28 days after transplantation. The measurement conditions in the leaf chamber, namely $\mathrm{CO}_{2}$ concentration, leaf temperature, airflow rate, and PPFD, were maintained at $400 \mu \mathrm{mol} \cdot \mathrm{mol}^{-1}, 25{ }^{\circ} \mathrm{C}, 500 \mathrm{~cm}^{3} \cdot \mathrm{s}^{-1}$ and $500 \mu \mathrm{mol} \cdot \mathrm{m}^{-2} \cdot \mathrm{s}^{-1}$, respectively. The SPAD values were measured with a portable chlorophyll meter (502, Minolta Camera Co., Ltd., Tokyo, Japan). All parameters were recorded for 6 plants $(n=6)$ in each replication.

\subsection{Measurement of Plant Growth Parameters}

After 28 days of transplanting, the shoot fresh and dry weights and stem length were measured. The stem length and shoot fresh weight were determined using a ruler and an electronic scale (EW220-3NM, Kern \& Sohn GmbH., Balingen, Germany), respectively. For determination of the shoot dry weight, samples were dried for one week in an oven (HB-502M; Hanback Sci, Suwon, Korea) at $70{ }^{\circ} \mathrm{C}$ and then weighed.

\subsection{Determination of the Individual Glucosinolate Concentration in Watercress}

The individual glucosinolate concentrations in the watercress were analyzed according to previous literature [28] but with some modifications. The shoots of watercress plants were collected at 28 days after transplanting, kept in a deep freezer at $-70{ }^{\circ} \mathrm{C}$ after soaking in liquid nitrogen, then moved to a dry freezer (TFD5503, IL Shinbiobase Co., Ltd., Seoul, Korea) at $-50{ }^{\circ} \mathrm{C}$ for 3 days and ground to powder. Glucosinolate was extracted in $70 \%(v / v)$ methanol with watercress powder $(0.1 \mathrm{~g})$ in a water bath for $5 \mathrm{~min}$. Afterward, the samples were centrifuged at $12,000 \times g$ for $10 \mathrm{~min}$, and the supernatant was analyzed as described by Lam et al. (2019) and Cuong et al. (2019) [28,29] to determine individual glucosinolate concentrations (glucobrassicin, 4-methoxyglucobrassicin, glucohirsutin, glucosiberin, and gluconasturtiin; Table 1). Desulfoglucosinolates were measured using a high-performance liquid chromatography (HPLC) system (1200 Infinity, Agilent Technologies, Santa Clara, CA, USA). An Inertsil ODS-3 (C18) column $150 \times 3.0 \mathrm{~mm}^{2}$ i.d., particle size $3 \mu \mathrm{m}$ (GL Science, Tokyo, Japan), was used with a column temperature of $40{ }^{\circ} \mathrm{C}$, a wavelength of $227 \mathrm{~nm}$, and a flow rate of $0.4 \mathrm{~mL} \cdot \mathrm{min}^{-1}$. The individual glucosinolates were measured by response factors (ISO 9167-1, 1992) [30] and the HPLC peak area ratios and with reference to a desulfosinigrin external standard. Glucosinolate contents $(\mu \mathrm{mol} / \mathrm{plant} \mathrm{DW})$ were presented as total glucosinolate concentration in the shoot $\left(\mu \mathrm{mol} \cdot \mathrm{g}^{-1} \mathrm{DW}\right)$ multiplied by shoot dry weight $(\mathrm{g})$.

\subsection{Statistical Analysis}

The growth and SPAD values were measured for six plants per replication. Photosynthetic parameters were measured for four plants per replication. The individual glucosinolate concentrations were measured for three plants per replication. For statistical analysis, one-way ANOVA was performed using SPSS 20.0 (SPSS, Inc., Chicago, IL, USA). Significant differences among treatments were verified at $p \leq 0.05$, using Tukey's multiple range test. 
Table 1. Relative response factor values of the desulfoglucosinolates from watercress shoot extracts and their retention times on C18 column [28].

\begin{tabular}{cccc}
\hline Common Name & Side Chain Structure & $\begin{array}{c}\text { Retention Time } \\
\text { (min) }\end{array}$ & Response Factor \\
\hline Glucobrassicin & indol-3-ylmethyl & 17.16 & 0.29 \\
4- Methoxyglucobrassicin & 4-methoxyindol-3- & 16.05 & 0.25 \\
Glucohirsutin & ylmethyl & 13.78 & 1.1 \\
Glucosiberin & 8-methylsulfinyloctyl & 16.77 & 1 \\
Gluconasturtiin & 2-phenylethyl & 15.68 & 0.95 \\
\hline
\end{tabular}

\section{Results}

\subsection{Plant Growth Parameters, Chlorophyll Content, and Photosynthetic Parameters}

The $12 \mathrm{~h}-266 \mu \mathrm{mol}, 16 \mathrm{~h}-200 \mu \mathrm{mol}$, and $20 \mathrm{~h}-160 \mu \mathrm{mol}$ treatments resulted in higher growth parameters relative to the $24 \mathrm{~h}-133 \mu \mathrm{mol}$ treatment. The shoot fresh and dry weights were significantly higher (1.15 and 1.42 times, respectively) under the $20 \mathrm{~h}-160 \mu \mathrm{mol}$ treatment compared to the $24 \mathrm{~h}-133 \mu \mathrm{mol}$ treatment (Figure $1 \mathrm{C}, \mathrm{D})$. How ever, the stem length and SPAD value of the watercress were not significantly affected by photoperiod and light intensity combinations (Figure 1A,B).
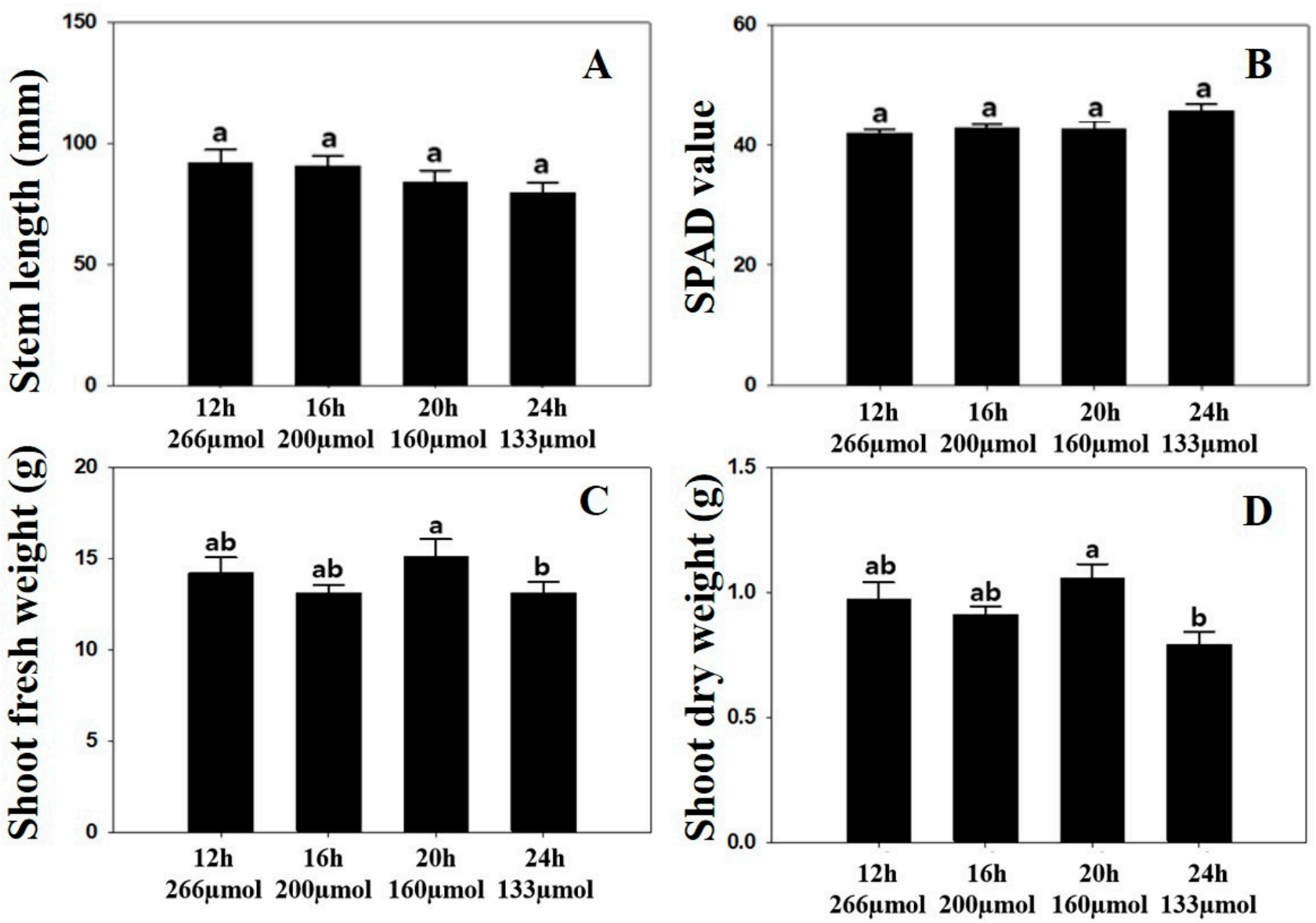

Figure 1. Stem length (A), SPAD value (B), shoot fresh weight (C), and shoot dry weight (D) under different lighting treatments of $12 \mathrm{~h}-266 \mu \mathrm{mol} \cdot \mathrm{m}^{-2} \cdot \mathrm{s}^{-1}, 16 \mathrm{~h}-200 \mu \mathrm{mol} \cdot \mathrm{m}^{-2} \cdot \mathrm{s}^{-1}, 20 \mathrm{~h}-160 \mu \mathrm{mol} \cdot \mathrm{m}^{-2} \cdot \mathrm{s}^{-1}$, and $24 \mathrm{~h}-133 \mu \mathrm{mol} \cdot \mathrm{m}^{-2} \cdot \mathrm{s}^{-1}$. Different letters above bars show significant differences at $p \leq 0.05$, using Tukey's multiple range test $(n=6)$.

The net photosynthesis and stomatal conductance were reduced with increasing photoperiod and decreasing light intensity (Figure 2). Specifically, the net photosynthesis 
under $16 \mathrm{~h}-200 \mu \mathrm{mol}, 20 \mathrm{~h}-160 \mu \mathrm{mol}$, and $24 \mathrm{~h}-133 \mu \mathrm{mol}$ treatments was $1.38,1.52$, and 3.32 times lower than that of $12 \mathrm{~h}-266 \mu \mathrm{mol}$ treatment in the study, respectively. The stomatal conductance under $16 \mathrm{~h}-200 \mu \mathrm{mol}, 20 \mathrm{~h}-160 \mu \mathrm{mol}$, and $24 \mathrm{~h}-133 \mu \mathrm{mol}$ treatments was $1.41,1.92$, and 2.08 times lower than that of $12 \mathrm{~h}-266 \mu \mathrm{mol}$ treatment in this study, respectively (Figure 2). Moreover, the shoot fresh and dry weights of the watercress were significantly low under lower light intensity and longer photoperiod treatments $(24 \mathrm{~h}-133 \mu \mathrm{mol})$ compared with $12 \mathrm{~h}-266 \mu \mathrm{mol}, 16 \mathrm{~h}-200 \mu \mathrm{mol}$, and $20 \mathrm{~h}-160 \mu \mathrm{mol}$ treatments. There was no significant difference in shoot fresh and dry weights among $12 \mathrm{~h}-266 \mu \mathrm{mol}, 16 \mathrm{~h}-200 \mu \mathrm{mol}$, and $20 \mathrm{~h}-160 \mu \mathrm{mol}$ treatments (Figure 1).
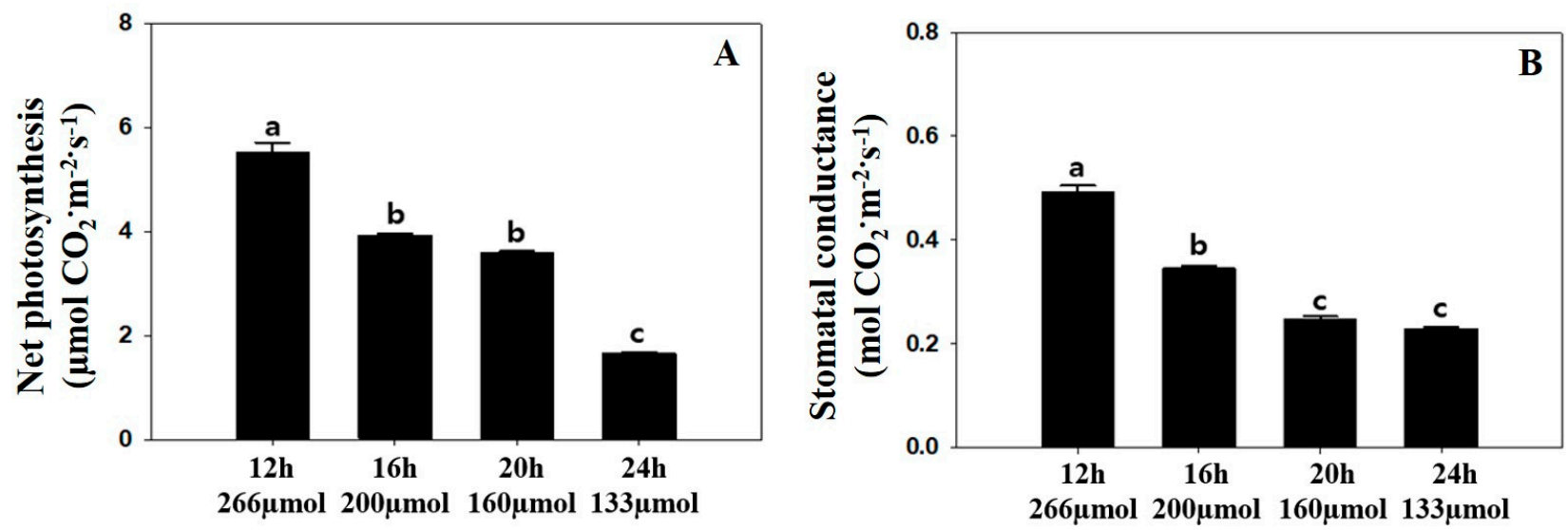

Figure 2. The net photosynthesis (A) and stomatal conductance (B) under different lighting treatments of $12 \mathrm{~h}-$ $266 \mu \mathrm{mol} \cdot \mathrm{m}^{-2} \cdot \mathrm{s}^{-1}, 16 \mathrm{~h}-200 \mu \mathrm{mol} \cdot \mathrm{m}^{-2} \cdot \mathrm{s}^{-1}, 20 \mathrm{~h}-160 \mu \mathrm{mol} \cdot \mathrm{m}^{-2} \cdot \mathrm{s}^{-1}$, and $24 \mathrm{~h}-133 \mu \mathrm{mol} \cdot \mathrm{m}^{-2} \cdot \mathrm{s}^{-1}$. Different letters above bars show significant differences at $p \leq 0.05$, using Tukey's multiple range test $(n=4)$.

\subsection{Total Glucosinolate Concentration and Content}

These analyses indicate that the watercress contained five different desulfoglucosinolates (glucohirsutin, 4-methoxyglucobrassicin, glucoiberin, glucohirsutin, and gluconasturtiin). Among the five desulfoglucosinolates identified, gluconasturtiin presented the highest concentration (Table 2). Gluconasturtiin accumulation in the shoot increased under $24 \mathrm{~h}-133 \mu \mathrm{mol}$ treatment and had the highest concentration $(82.51 \%$ of the total glucosinolate concentration). However, there was no significant difference in gluconasturtiin concentration among $24 \mathrm{~h}-133 \mu \mathrm{mol}, 16 \mathrm{~h}-200 \mu \mathrm{mol}$, and $20 \mathrm{~h}-160 \mu \mathrm{mol}$ treatments or between $20 \mathrm{~h}-160 \mu \mathrm{mol}$ and $12 \mathrm{~h}-266 \mu \mathrm{mol}$ treatments. The highest glucosiberin, 4-methoxyglucobrassicin, and glucohirsutin concentrations $(13.61 \%, 3.79 \%$, and $2.39 \%$ of the total glucosinolates, respectively) were observed under $20 \mathrm{~h}-160 \mu \mathrm{mol}$ treatment. There was no significant difference in glucosiberin concentration among $24 \mathrm{~h}-133 \mu \mathrm{mol}, 16 \mathrm{~h}-200 \mu \mathrm{mol}$, and $12 \mathrm{~h}-266 \mu \mathrm{mol}$ treatments. There was no significant difference in glucohirsutin concentration among four treatments $(24 \mathrm{~h}-133 \mu \mathrm{mol}$, $16 \mathrm{~h}-200 \mu \mathrm{mol}, 12 \mathrm{~h}-266 \mu \mathrm{mol}$, and $20 \mathrm{~h}-160 \mu \mathrm{mol})$. There was no significant difference in 4-methoxyglucobrassicin concentration among $24 \mathrm{~h}-133 \mu \mathrm{mol}, 16 \mathrm{~h}-200 \mu \mathrm{mol}$, and $20 \mathrm{~h}-160 \mu \mathrm{mol}$ treatments or among $24 \mathrm{~h}-133 \mu \mathrm{mol}, 16 \mathrm{~h}-200 \mu \mathrm{mol}$, and $12 \mathrm{~h}-266 \mu \mathrm{mol}$ treatments. The highest glucobrassicin concentration $(8.80 \%$ of the total glucosinolate) was recorded under $24 \mathrm{~h}-133 \mu \mathrm{mol}$ treatment. There was no significant difference in glucobrassicin concentration among $24 \mathrm{~h}-133 \mu \mathrm{mol}, 16 \mathrm{~h}-200 \mu \mathrm{mol}$, and $12 \mathrm{~h}-266 \mu \mathrm{mol}$ treatments (Table 2). Overall, the total glucosinolate concentration was the greatest at $24 \mathrm{~h}-133 \mu \mathrm{mol}$ treatment and was 1.28-fold higher than that of the $12 \mathrm{~h}-266 \mu \mathrm{mol}$ treatment. There were no significant differences in total glucosinolate concentration in shoots between the $12 \mathrm{~h}$ and $16 \mathrm{~h}$ treatments or $20 \mathrm{~h}$ and $24 \mathrm{~h}$ treatments (Figure $3 \mathrm{~A}$ ). However, the total glucosinolate content in the shoot was the highest under $20 \mathrm{~h}-160 \mu \mathrm{mol}$ treatment because glucosinolate contents ( $\mu \mathrm{mol} /$ plant $\mathrm{DW})$ were presented as total glucosinolate concentration in the shoot ( $\left.\mu \mathrm{mol} \mathrm{g}{ }^{-1} \mathrm{DW}\right)$ multiplied by shoot dry weight $(\mathrm{g})$. There were 
no significant differences in total glucosinolate content in shoot among $24 \mathrm{~h}-133 \mu \mathrm{mol}$, $16 \mathrm{~h}-200 \mu \mathrm{mol}$, and $12 \mathrm{~h}-266 \mu \mathrm{mol}$ treatments (Figure 3B).

Table 2. The individual glucosinolate concentration of watercress under different lighting treatments of $12 \mathrm{~h}-266 \mu \mathrm{mol} \cdot \mathrm{m}^{-2} \cdot \mathrm{s}^{-1}$, $16 \mathrm{~h}-200 \mu \mathrm{mol} \cdot \mathrm{m}^{-2} \cdot \mathrm{s}^{-1}, 20 \mathrm{~h}-160 \mu \mathrm{mol} \cdot \mathrm{m}^{-2} \cdot \mathrm{s}^{-1}$, and $24 \mathrm{~h}-133 \mu \mathrm{mol} \cdot \mathrm{m}^{-2} \cdot \mathrm{s}^{-1}$.

\begin{tabular}{|c|c|c|c|c|c|}
\hline \multirow[t]{2}{*}{ Lighting Treatment } & \multicolumn{5}{|c|}{$\begin{array}{l}\text { Individual Glucosinolate Concentration in Watercress Shoots } \\
\qquad\left(\mathrm{mg} \cdot \mathrm{g}^{-1} \mathrm{DW}\right)^{\mathrm{z}}\end{array}$} \\
\hline & Siber & Hirsu & Brassi & Metho & Nastur \\
\hline $12 \mathrm{~h}-266 \mu \mathrm{mol}$ & $1.04 \mathrm{~b}$ & 0.53 & $1.83 \mathrm{ab}$ & $0.58 b$ & $15.69 b$ \\
\hline $16 \mathrm{~h}-200 \mu \mathrm{mol}$ & $0.63 b$ & 0.45 & $1.75 \mathrm{ab}$ & $0.68 \mathrm{ab}$ & $18.92 \mathrm{a}$ \\
\hline $20 \mathrm{~h}-160 \mu \mathrm{mol}$ & $3.36 \mathrm{a}$ & 0.59 & $1.40 \mathrm{~b}$ & $0.94 a$ & $18.81 \mathrm{ab}$ \\
\hline $24 \mathrm{~h}-133 \mu \mathrm{mol}$ & $0.46 \mathrm{~b}$ & 0.53 & $2.21 \mathrm{a}$ & $0.79 \mathrm{ab}$ & $20.71 \mathrm{a}$ \\
\hline Significance $\mathrm{y}$ & $* * *$ & NS & $* *$ & $* * *$ & $*$ \\
\hline
\end{tabular}

${ }^{\mathrm{z}}$ Siber: glucosiberin, Hirsu: glucohirsutin, Brassi: glucobrassicin, Metho: 4-methoxyglucobrassicin, Nastur: gluconasturtiin. ${ }^{\mathrm{y}}$ Different letters show a significant difference within each treatment according to Tukey's multiple range test at Not Significant (NS) ( $p>0.05)$, ${ }^{*} p \leq 0.05 ;{ }^{* *} p<0.01$; and ${ }^{* * *} p<0.001(n=3)$.
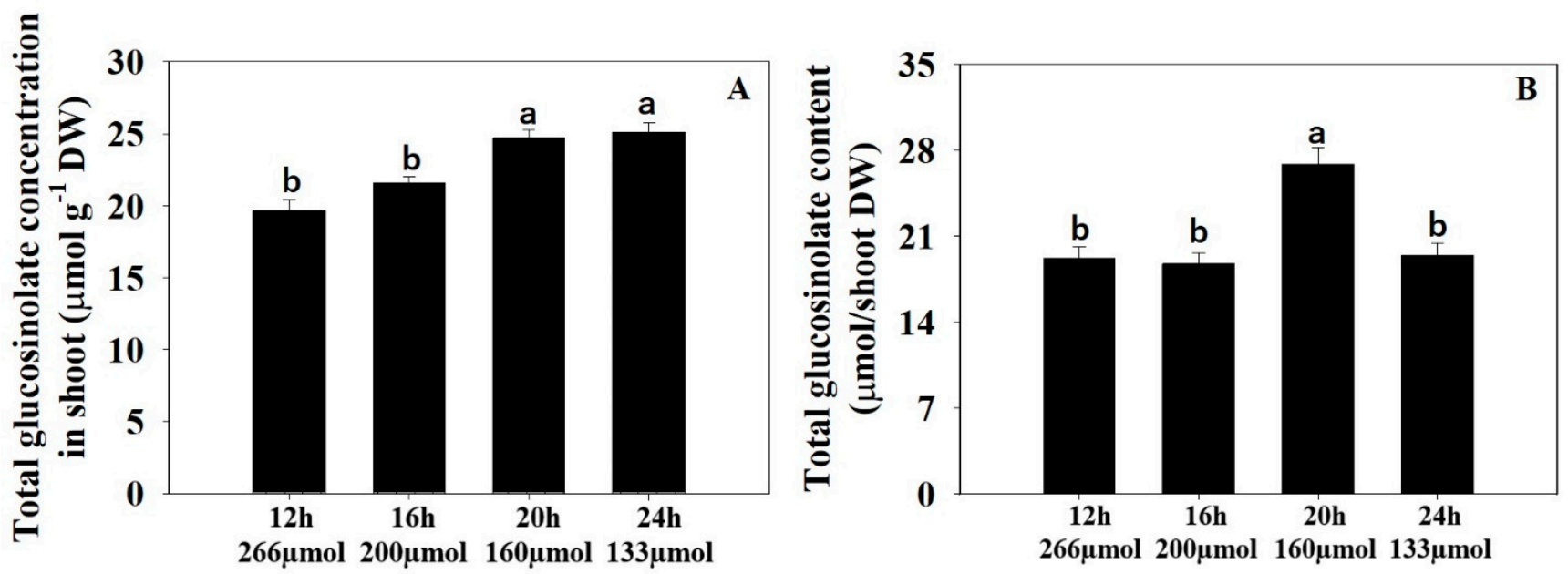

Figure 3. The glucosinolate concentration (A) and content (B) in watercress shoots under different lighting treatments of $12 \mathrm{~h}-266 \mu \mathrm{mol} \cdot \mathrm{m}^{-2} \cdot \mathrm{s}^{-1}, 16 \mathrm{~h}-200 \mu \mathrm{mol} \cdot \mathrm{m}^{-2} \cdot \mathrm{s}^{-1}, 20 \mathrm{~h}-160 \mu \mathrm{mol} \cdot \mathrm{m}^{-2} \cdot \mathrm{s}^{-1}$, and $24 \mathrm{~h}-133 \mu \mathrm{mol} \cdot \mathrm{m}^{-2} \cdot \mathrm{s}^{-1}$. Different letters above bars show significant differences at $p \leq 0.05$, using Tukey's multiple range test $(n=3)$.

\section{Discussion}

\subsection{Plant Growth Parameters, Chlorophyll Content, and Photosynthetic Parameters}

Previous reports have indicated that higher light intensities enhanced growth and promoted crop production [31,32]. This was possible because of the wider expansion of the leaf under the higher light intensity treatment. A larger leaf leads to more light interception, which might have resulted in a significant increment in the shoot fresh and dry weights under higher light intensity [31]. The growth of ice plants under a fluorescent lamp, red LEDs, and blue LEDs was significantly higher under a higher light intensity treatment $\left(150 \mu \mathrm{mol} \cdot \mathrm{m}^{-2} \cdot \mathrm{s}^{-1}\right)$ than under a lower light intensity treatment $\left(120 \mu \mathrm{mol} \cdot \mathrm{m}^{-2} \cdot \mathrm{s}^{-1}\right)$ [20]. The biomass, stem diameter, and root/shoot ratio of soybean were higher under 400 and $500 \mu \mathrm{mol} \cdot \mathrm{m}^{-2} \cdot \mathrm{s}^{-1}$ than under $100 \mu \mathrm{mol} \cdot \mathrm{m}^{-2} \cdot \mathrm{s}^{-1}$ [33]. The leaf area was reduced by shade conditions [34]. Similarly, plant dry matter production of soybean decreased with decreasing light intensity [35]. Leaf fresh weight of Arabidopsis thaliana was significantly higher under a higher light intensity as compared to that of plants grown under a low light intensity at 6 weeks after transplanting [36]. Moreover, the fresh weight of watercress subjected to a long day ( $16 \mathrm{~h}$ ) was significantly higher than that subjected to a short day $(8 \mathrm{~h})$ [26]. The fresh and dry weights of quinoa increased under a short photoperiod and 
high light intensity treatment [37]. Likewise, the biomass of the watercress increased under high light intensity and short photoperiod treatments.

Reductions in light intensity may influence the carbon balance in the plant. Rates of physiological process increase, while the photosynthetic yield decreases [33]. Normally, it is expected that the shading conditions or lower light intensities restrict leaf growth and result in smaller leaf areas with thinner leaves, reduced chlorophyll content, and thinner palisade tissues, leading to lower light-harvesting [38,39]. Furthermore, there is a reduction in stomatal conductance and density, which leads to poor $\mathrm{CO}_{2}$ transportation under low light conditions. The electron transition from PSII to PSI is obstructed, whereas the activity and number of enzymes that participate in the Calvin cycle undergo a change. All of this results in a reduced carbon dioxide assimilation rate and a reduced net photosynthetic rate under low light conditions [33]. Previous reports have indicated that the main biochemical restraint related to shadow-associated down-adjustment of net photosynthetic rate is a decrease in the activity or amount of rubisco $[33,40]$. Photosynthetic capacity was reduced under low light conditions because carbon was restricted [41]. For example, low light intensity reduced the photosynthesis rate in pak choi [42] and soybean [33]. Thus, the net photosynthesis and stomatal conductance were reduced with increasing photoperiod and decreasing light intensity.

\subsection{Total Glucosinolate Concentration and Content}

Glucosinolates are bioactive compounds typically found in cruciferous group plants. It has been indicated that long days could enhance glucosinolate accumulation in Arabidopsis [43] and watercress [26]. Low light intensity increased the concentrations of 4-methoxyglucobrassicin, glucobrassicin, and neoglucobrassicin in pak choi [44]. The antioxidant activity and the total phenolic content of Orthosiphon stamineus under an open environment were higher than shade-grown conditions [45]. Total phenolic content in the leaves of Ipomoea batatas was higher under 16 than $8 \mathrm{~h}$ at a light intensity of $150 \mu \mathrm{mol} \cdot \mathrm{m}^{-2} \cdot \mathrm{s}^{-1}$ [46]. Antioxidant capacity and total phenolic content in lettuce continuously increased with increasing photoperiods in $150 \mu \mathrm{mol} \cdot \mathrm{m}^{-2} \cdot \mathrm{s}^{-1}$ conditions. Specifically, the phenolic content in lettuce was highest at $24 \mathrm{~h}$ under $150 \mu \mathrm{mol} \cdot \mathrm{m}^{-2} \cdot \mathrm{s}^{-1}$ and was 5.3-fold higher than under a $12 \mathrm{~h}$ period treatment [47]. Likewise, in the results of this experiment, total glucosinolate concentration was significantly higher under $20 \mathrm{~h}-160 \mu \mathrm{mol}$ and $24 \mathrm{~h}-133 \mu \mathrm{mol}$ compared with $12 \mathrm{~h}-266 \mu \mathrm{mol}$ and $16 \mathrm{~h}-200 \mu \mathrm{mol}$. This indicates that the long photoperiods had a more photomorphogenic effect than a photosynthetic one. However, the total glucosinolate concentration was not significantly different between the 20 and $24 \mathrm{~h}$ photoperiods. The results indicate that the total glucosinolate concentration could increase with increasing photoperiods under low light intensity. However, it might reach a saturation point under low light intensity and long photoperiod. Expanding the photoperiod in weak light intensity conditions has a slight compensatory effect because it can decrease the negative influences of the weak light stress.

\section{Conclusions}

The results indicated that a photoperiod of $20 \mathrm{~h}$ at $160 \mu \mathrm{mol} \cdot{ }^{-2} \cdot \mathrm{s}^{-1}$ enhanced total glucosinolate content and plant biomass of watercress grown in a plant factory. Further studies can investigate the influence of light quality from LEDs on the productivity and bioactive compounds of watercress grown in a plant factory. Moreover, the results also suggested that longer photoperiod induction was a potential method for watercress glucosinolate production. There is great potential to apply these results to improve the quality of watercress plants and enhance the efficiency in watercress cultivation in plant factories.

Author Contributions: V.P.L. conducting the experiment, data collection and analysis, writing —original manuscript, writing-review and editing. J.C. conducting the experiment, data collection and analysis. J.P. Project administration, supervision, constructing the idea, experimental design, data analysis, writing-original manuscript, writing-review, and editing. All authors have read and agreed to the published version of the manuscript. 
Funding: This research work was supported by Institute of Information \& communications Technology Planning \& Evaluation (IITP) grant funded by the Korean government (MSIT) (No. 2020-0-01441, Artificial Intelligence Conver-gence Research Center (Chungnam National University)).

Institutional Review Board Statement: Not applicable.

Informed Consent Statement: Not applicable.

Data Availability Statement: Not applicable.

Conflicts of Interest: The authors declare no conflict of interest.

\section{References}

1. Zeb, A. Phenolic profile and antioxidant potential of wild watercress (Nasturtium officinale L.). Springerplus 2015, 4, 714. [CrossRef] [PubMed]

2. Klimek-Szczykutowicz, M.; Szopa, A.; Ekiert, H. Chemical composition, traditional and professional use in medicine, application in environmental protection, position in food and cosmetics industries, and biotechnological studies of Nasturtium officinale (watercress)—A review. Fitoterapia 2018, 129, 283-292. [CrossRef] [PubMed]

3. EFSA European Food Safety Authority (EFSA). Available online: http:/ / www.efsa.europa.eu/ (accessed on 25 January 2020).

4. Noia, J.D. Defining powerhouse fruits and vegetables: A nutrient density approach. Prev. Chronic. Dis. 2014, 11, 130390. [CrossRef] [PubMed]

5. Suroowan, S.; Mahomoodally, M.F. A comparative ethnopharmacological analysis of traditional medicine used against respiratory tract diseases in Mauritius. J. Ethnopharmacol. 2016, 177, 61-80. [CrossRef]

6. Zafar, R.; Zahoor, M.; Shah, A.; Majid, F. Determination of antioxidants and antibacterial activities, total phenolic, polyphenol and pigment contents in Nasturtium officinale. Pharmacologyonline 2017, 1, 11-18.

7. Klimek-Szczykutowicz, M.; Dziurka, M.; Blazevic, I.; Dulovic, A.; Granica, S.; Korona-Glowniak, I.; Ekiert, H.; Szopa, A. Phytochemical and biological activity studies on Nasturtium officinale (watercress) microshoot cultures grown in rita(r) temporary immersion systems. Molecules 2020, 25, 5257. [CrossRef]

8. Al-Kodmany, K. The vertical farm: A review of developments and implications for the vertical city. Buildings 2018, 8, 24. [CrossRef]

9. Ali, S.; Liu, Y.; Ishaq, M.; Shah, T.; Abdullah; Ilyas, A.; Din, I.U. Climate change and its impact on the yield of major food crops: Evidence from pakistan. Foods 2017, 6, 39. [CrossRef]

10. Zhao, C.; Liu, B.; Piao, S.L.; Wang, X.H.; Lobell, D.B.; Huang, Y.; Huang, M.T.; Yao, Y.T.; Bassu, S.; Ciais, P.; et al. Temperature increase reduces global yields of major crops in four independent estimates. Proc. Natl. Acad. Sci. USA 2017, 114, 9326-9331. [CrossRef]

11. Kozai, T. Resource use efficiency of closed plant production system with artificial light: Concept, estimation and application to plant factory. Proc. Jpn. Acad. Ser. 2013, 89, 447-461. [CrossRef]

12. Kozai, T. Sustainable plant factory: Closed plant production systems with artificial light for high resource use efficiencies and quality produce. Acta Hortic. 2013, 1004, 27-40. [CrossRef]

13. Zakurin, A.O.; Shchennikova, A.V.; Kamionskaya, A.M. Artificial-light culture in protected ground plant growing: Photosynthesis, photomorphogenesis, and prospects of LED application. Russ. J. Plant Physl. 2020, 67, 413-424. [CrossRef]

14. Liu, Y.; Ren, X.X.; Jeong, B.R. Supplementary Light source affects growth, metabolism, and physiology of Adenophora triphylla (thunb.) A.DC. seedlings. Biomed. Res. Int. 2019, 2019. [CrossRef]

15. Mao, H.P.; Hang, T.; Zhang, X.D.; Lu, N. Both multi-segment light intensity and extended photoperiod lighting strategies, with the same daily light integral, promoted lactuca sativa 1. growth and photosynthesis. Agronomy 2019, 9, 857. [CrossRef]

16. Kitaya, Y.; Niu, G.; Kozai, T.; Ohashi, M. Photosynthetic photon flux, photoperiod, and $\mathrm{CO}_{2}$ concentration affect growth and morphology of lettuce plug transplants. HortScience 1998, 33, 988-991. [CrossRef]

17. Vlahos, J.; Heuvelink, E.; Martakis, G. A growth analysis study of three Achimenes cultivars grown under three light regimes. Sci. Hortic. 1991, 46, 275-282. [CrossRef]

18. Zha, L.Y.; Liu, W.K. Effects of light quality, light intensity, and photoperiod on growth and yield of cherry radish grown under red plus blue LEDs. Hortic. Environ. Biote 2018, 59, 511-518. [CrossRef]

19. Lu, N.; Bernardo, E.L.; Tippayadarapanich, C.; Takagaki, M.; Kagawa, N.; Yamori, W. Growth and accumulation of secondary metabolites in perilla as affected by photosynthetic photon flux density and electrical conductivity of the nutrient solution. Front. Plant Sci. 2017, 8, 708. [CrossRef]

20. Kim, Y.J.; Kim, H.M.; Kim, H.M.; Jeong, B.R.; Lee, H.J.; Kim, H.J.; Hwang, S.J. Ice plant growth and phytochemical concentrations are affected by light quality and intensity of monochromatic light-emitting diodes. Hortic. Environ. Biote 2018, 59, 529-536. [CrossRef]

21. Fan, X.X.; Xu, Z.G.; Liu, X.Y.; Tang, C.M.; Wang, L.W.; Han, X.L. Effects of light intensity on the growth and leaf development of young tomato plants grown under a combination of red and blue light. Sci. Hortic. 2013, 153, 50-55. [CrossRef] 
22. Kang, J.H.; KrishnaKumar, S.; Atulba, S.L.S.; Jeong, B.R.; Hwang, S.J. Light intensity and photoperiod influence the growth and development of hydroponically grown leaf lettuce in a closed-type plant factory system. Hortic. Environ. Biote 2013, 54, 501-509. [CrossRef]

23. Yin, Y.H.; Yu, C.J.; Yu, L.; Zhao, J.S.; Sun, C.J.; Ma, Y.B.; Zhou, G.K. The influence of light intensity and photoperiod on duckweed biomass and starch accumulation for bioethanol production. Bioresour. Technol. 2015, 187, 84-90. [CrossRef] [PubMed]

24. Rehman, M.; Ullah, S.; Bao, Y.; Wang, B.; Peng, D.; Liu, L. Light-emitting diodes: Whether an efficient source of light for indoor plants? Environ. Sci. Pollut. Res. Int. 2017, 24, 24743-24752. [CrossRef] [PubMed]

25. Taulavuori, E.; Taulavuori, K.; Holopainen, J.K.; Julkunen-Tiitto, R.; Acar, C.; Dincer, I. Targeted use of LEDs in improvement of production efficiency through phytochemical enrichment. J. Sci. Food Agric. 2017, 97, 5059-5064. [CrossRef] [PubMed]

26. Engelen-Eigles, G.; Holden, G.; Cohen, J.D.; Gardner, G. The effect of temperature, photoperiod, and light quality on gluconasturtiin concentration in watercress (Nasturtium officinale R. Br.). J. Agric. Food Chem. 2006, 54, 328-334. [CrossRef] [PubMed]

27. Choi, J.Y.; Kim, S.J.; Bok, K.J.; Lee, K.Y.; Park, J.S. Effect of different nutrient solution and light quality on growth and glucosinolate contents of watercress in hydroponics. J. Bio-Environ. Control 2018, 27, 371-380. [CrossRef]

28. Lam, V.P.; Choi, J.; Kim, S.; Park, J.; Hernandez, R. Optimizing plant spacing and harvest time for yield and glucosinolate accumulation in watercress (Nasturtium officinale L.) grown in a hydroponic system. Hortic. Sci. Technol. 2019, 37, 733-743. [CrossRef]

29. Cuong, D.M.; Park, C.H.; Bong, S.J.; Kim, N.S.; Kim, J.K.; Park, S.U. Enhancement of glucosinolate production in watercress (Nasturtium officinale) hairy roots by overexpressing cabbage transcription factors. J. Agric. Food Chem. 2019, 67, 4860-4867. [CrossRef]

30. ISO Norm. Rapeseed-Determination of glucosinolate content. Part 1: Method using high-performance liquid chromatography. ISO 1992, 9167, 1-9.

31. Li, Q.; Kubota, C. Effects of supplemental light quality on growth and phytochemicals of baby leaf lettuce. Environ. Exp. Bot. 2009, 67, 59-64. [CrossRef]

32. Solovchenko, A.E.; Khozin-Goldberg, I.; Didi-Cohen, S.; Cohen, Z.; Merzlyak, M.N. Effects of light intensity and nitrogen starvation on growth, total fatty acids and arachidonic acid in the green microalga Parietochloris Incisa. J. Appl. Phycol. 2008, 20, 245-251. [CrossRef]

33. Feng, L.Y.; Raza, M.A.; Li, Z.C.; Chen, Y.K.; Bin Khalid, M.H.; Du, J.B.; Liu, W.G.; Wu, X.L.; Song, C.; Yu, L.; et al. The influence of light intensity and leaf movement on photosynthesis characteristics and carbon balance of soybean. Front. Plant Sci. 2019, 9, 1952. [CrossRef] [PubMed]

34. Gommers, C.M.M.; Visser, E.J.W.; Onge, K.R.S.; Voesenek, L.A.C.J.; Pierik, R. Shade tolerance: When growing tall is not an option. Trends Plant Sci. 2013, 18, 65-71. [CrossRef]

35. Yang, F.; Huang, S.; Gao, R.C.; Liu, W.G.; Yong, T.W.; Wang, X.C.; Wu, X.L.; Yang, W.Y. Growth of soybean seedlings in relay strip intercropping systems in relation to light quantity and red:far-red ratio. Field. Crop Res. 2014, 155, 245-253. [CrossRef]

36. Schumann, T.; Paul, S.; Melzer, M.; Dormann, P.; Jahns, P. Plant growth under natural light conditions provides highly flexible short-term acclimation properties toward high light stress. Front. Plant Sci. 2017, 8. [CrossRef] [PubMed]

37. Austin, J.; Jeon, Y.A.; Cha, M.-K.; Park, S.; Cho, Y.-Y. Effects of photoperiod, light intensity and electrical conductivity on the growth and yield of quinoa (Chenopodium quinoa Willd.) in a closedtype plant factory system. Hortic. Sci. Technol. 2016, 34, 405-413 [CrossRef]

38. Gong, W.Z.; Qi, P.F.; Du, J.B.; Sun, X.; Wu, X.L.; Song, C.; Liu, W.G.; Wu, Y.S.; Yu, X.B.; Yong, T.W.; et al. Transcriptome analysis of shade-induced inhibition on leaf size in relay intercropped soybean. PLoS ONE 2014, 9, e98465. [CrossRef] [PubMed]

39. Shafiq, I.; Hussain, S.; Raza, M.A.; Iqbal, N.; Ahsan Asghar, M.; Raza, A.; Fan, Y.F.; Mumtaz, M.; Shoaib, M.; Ansar, M.; et al. Crop photosynthetic response to light quality and light intensity. J. Integr. Agric. 2021, 20, 4-23. [CrossRef]

40. Cen, Y.P.; Sage, R.F. The regulation of rubisco activity in response to variation in temperature and atmospheric $\mathrm{CO}_{2}$ partial pressure in sweet potato. Plant Physiol. 2005, 139, 979-990. [CrossRef] [PubMed]

41. Su, B.Y.; Song, Y.X.; Song, C.; Cui, L.; Yong, T.W.; Yang, W.Y. Growth and photosynthetic responses of soybean seedlings to maize shading in relay intercropping system in Southwest China. Photosynthetica 2014, 52, 332-340. [CrossRef]

42. Zhu, H.F.; Li, X.F.; Zhai, W.; Liu, Y.; Gao, Q.Q.; Liu, J.P.; Ren, L.; Chen, H.Y.; Zhu, Y.Y. Effects of low light on photosynthetic properties, antioxidant enzyme activity, and anthocyanin accumulation in purple pak-choi (Brassica campestris ssp Chinensis Makino). PLoS ONE 2017, 12, e0179305. [CrossRef] [PubMed]

43. Huseby, S.; Koprivova, A.; Lee, B.R.; Saha, S.; Mithen, R.; Wold, A.B.; Bengtsson, G.B.; Kopriva, S. Diurnal and light regulation of sulphur assimilation and glucosinolate biosynthesis in Arabidopsis. J. Exp. Bot. 2013, 64, 1039-1048. [CrossRef]

44. Yang, J.; Zhu, Z.J.; Gerendas, J. Interactive effects of phosphorus supply and light intensity on glucosinolates in pakchoi (Brassica campestris L. ssp chinensis var. communis). Plant Soil. 2009, 323, 323-333. [CrossRef]

45. Farhan, M.; Razak, S.A.; Pin, K.Y.; Chuah, A.L. Antioxidant activity and phenolic content of different parts of Orthosiphon stamineus grown under different light intensities. J. Trop. Sci. 2012, 24, 173-177.

46. Carvalho, I.S.; Cavaco, T.; Carvalho, L.M.; Duque, P. Effect of photoperiod on flavonoid pathway activity in sweet potato (Ipomoea batatas (L.) Lam.) leaves. Food Chem. 2010, 118, 384-390. [CrossRef]

47. Cho, J.Y.; Yoo, K.S.; Kim, J.; Choi, B.J.; Oh, W. Growth and bioactive compounds of lettuce as affected by light intensity and photoperiod in a plant factory using external electrode fluorescent lamps. Hortic. Sci. Technol. 2020, 38, 645-659. [CrossRef] 